DOI: $10.17805 / z p u .2016 .3 .3$

\title{
Нормативно-методические основы стандартизации в сфере труда и образования: российский и международный опыт
}

\author{
А. Д. БОРОДАЙ \\ (МОСКОВСКИЙ ГУМАНИТАРНЫЙ УНИВЕРСИТЕТ), \\ А. Г. ГОЛОВА \\ (РОССИЙСКИЙ ГОСУДАРСТВЕННЫЙ ГУМАНИТАРНЫЙ УНИВЕРСИТЕТ)
}

Президент России В. В. Путин поставил задачу по развитию трудовых ресурсов и совершенствованию трудовых отношений в стране прежде всего через сопряжение сферы образования и труда, создание единой национальной системы квалификаций и механизмов повышения квалификационного уровня. С этой целью создается правовая основа для регулирования новых форм отношений на рынке труда и специализированный орган - Национальный совет при Президенте Российской Федерации по профессиональным квалификациям, консолидирующий представителей работодателей, образования и государства. В статье раскрывается преемственность российского и международного опыта реформ в сфере труда и образования в контексте интеграции России в единое европейское экономическое пространство вне зависимости от политической конъюнктуры.

Глобализационные процессы и возрастающая мобильность населения мира обусловливают создание интернациональной универсальной системы регулирования рынка труда и развития трудовых ресурсов через унификацию информации и документооборота, создание единых принципов профессионального образования и обучения, сертификации кадров. Все это нашло реализацию в так называемом Болонском процессе высшего образования, который трансформировался в Копенгагенский процесс всей системы профессионального обучения и подготовки. В результате выработаны универсальные инструменты, такие как EUROPASS, Европейская кредитная система (ECTS), Европейская квалификационная рамка (EQF), Европейская система обеспечения качества профессионального образования и обучения, включающая независимую экспертизу и сертификацию как образовательных программ, так и кадров.

Нормы и правила, выработанные в международной практике для обеспечения данных процессов, в настоящее время адаптируются для российской действительности. Особым механизмом становятся профессиональные и образовательные стандарты, которые также опираются на единую методическую базу.

Отмечается, что траектории развития стандартизации в сфере труда и образования в станах европейского континента, Великобритании и в государствах постсоветского пространства различны. Особое внимание уделяется российской практике систематизации различной профессиональной деятельности и видов занятости, требований к квалификациям персонала как основе стандартизации в сфере труда. Делается вывод о значении реформ в области образования и трудовых отношений в эффективности и устойчивости российской экономики.

Ключевые слова: профессиональные стандарты; образовательные стандарты; Национальная квалификационная рамка; Болонский процесс; Копенгагенский процесс

\section{BВЕАЕНИЕ}

B майских указах 2012 г. Президента РФ В. В. Путина была сформулирована задача по радикальному совершенствованию профессиональной системы квалификаций в различных отраслях экономики, культуры и образования Российской Федерации. Собственную позицию, обосновывавшую необходимость реформ, Пре- 
зидент разъяснил в статье, которая была опубликована в газете «Комсомольская правда». В ней подчеркивалось, что проблему «работы социальных лифтов» можно решить через конструирование индивидуальных карьерных траекторий, т. е. «продвижения каждого человека на основе его способностей и таланта» (Путин, 2012: 1), формируя механизмы, повышающие достоверность оценки квалификации нанимаемого сотрудника со стороны работодателя. В этой программной статье была поставлена конкретная задача перед Правительством РФ, которое должно в сотрудничестве с профессиональными и предпринимательскими объединениями, а также университетами создать Национальный план развития профессиональных стандартов (там же). Последующие решения Правительства РФ продемонстрировали понимание необходимости учета не только интересов, но и совмещения алгоритмов развития трудовых ресурсов, работодателей и сферы образования.

В декабре 2015 г. состоялся Всероссийский форум «Национальная система квалификаций России. Практические шаги системных изменений». Он проводился Российским союзом промышленников и предпринимателей (РСПП), Министерством труда и социальной защиты РФ под әгидой Национального совета при Президенте Российской Федерации по профессиональным квалификациям. В приветствии к участникам форума президент РСПП А. Н. Шохин отметил: «Национальная система квалификаций, которая создается в Российской Федерации под руководством Национального совета, позволит решить ряд стратегических задач, способствующих повышению эффективности и гибкости рынка труда. Среди них: сближение рынка образовательных услуг и рынка труда, устранение профессионально-квалификационных диспропорций спроса и предложения рабочей силы. Профессиональный стандарт как базовая единица национальной системы квалификаций представляет собой “социальный заказ” предпринимателей, адресованный как системе профессионального образования, так и рынку труда и задающий требования к качеству рабочей силы, необходимой для создания эффективных рабочих мест» (Состоялся Всероссийский форум ... : Электронный ресурс).

На форуме отмечалось, что актуальность модернизации рынка труда и занятости, и частности системы квалификаций кадров, продиктована современными вызовами, возникающими перед российской экономикой. А. Н. Шохин отметил: «Последствия мирового экономического кризиса и обострение внешнеполитической обстановки требуют принятия кардинальных мер по замещению импорта продукцией российских производителей. Существенным ограничением в решении задач импортозамещения может стать дефицит высококвалифицированных кадров» (Приветствие президента Российского союза ... : Электронный ресурс). Решение этой проблемы возможно только при условии постоянного развития человеческих ресурсов, в том числе через обучение по образовательным программам повышения профессиональной квалификации и переподготовки.

Одной из задач в области становления национальной системы квалификаций является формирование сети центров независимой оценки квалификации. При этом в национальную систему квалификаций будет инкорпорирована профессионально-общественная аккредитация профессиональных образовательных программ, которая будет проводиться работодателями. Это позволит предпринимательскому сообществу более эффективно влиять на рынок образовательных услуг в сфере профессионального образования. Наряду с этим не преодолеваются нега- 
тивные тенденции в подготовке квалифицированных кадров, особенно рабочих и техников.

Аля образовательных организаций национальная система квалификаций станет не только стимулом для повышения качества профессиональной подготовки, но и эффективным инструментом для привлечения финансовых ресурсов: государственного заказа на подготовку кадров, корпоративных инвестиций, средств населения. Рейтинг оценки работодателями образовательных организаций будет формироваться как интегральный показатель результатов независимой оценки квалификации выпускников и профессионально-общественной аккредитации профессиональных образовательных программ.

Система высшего образования Российской Федерации готовится к новым реалиям с учетом Федерального закона от 2 мая 2015 г. № 122-Ф3 «О внесении изменений в Трудовой кодекс Российской Федерации и статьи 11 и 73 Федерального закона “Об образовании в Российской Федерации" (Федеральный закон Российской Федерации от 2 мая 2015 г. № 122-Ф3 ... , 2015: Электронный ресурс), на основании которого с июля 2016 г. вступает в силу обязательное использование профессиональных стандартов (ПС) при их наличии в кадровом документообороте. Этот закон уточняет порядок разработки, утверждения и применения ПС, а также закрепляет их роль в формировании требований к результатам освоения образовательных программ, тем самым обеспечивая связь рынка труда и образования. В разъяснениях Минтруда РФ по использованию данных нормативов сказано, что «при установлении квалификационных и профессиональных требований к соискателям и работникам ПС являются ориентирами и могут применяться в части наименования должностей, профессий и специальностей, определения трудовых функций, требований к образованию и опыту работы с учетом особенностей, обусловленных технологией и организацией производства и труда у данного работодателя» (Минтруда России дает разъяснения ..., 2016: Электронный ресурс). Аинамика изменений показательна на примере учреждения двух стандартов. Это стандарт «Специалист по управлению персоналом», который вводится приказом Минтруда РФ, подписанным 6 октября 2015 г. Синхронно приказом Министерства образования и науки РФ от 14 декабря 2015 г. утверждается ФГОС по направлению 38.03.03 - «Управление персоналом (уровень бакалавриата)». В тех областях, где ПС не разработан, идет модернизация существующего ФГОС через корректировку компетенций, увеличения разных форм практик, обязательности участия представителей работодателей в итоговой аттестации выпускника, общественную аккредитацию образовательных программ (через союзы работодателей). На уровне рабочих программ дисциплин стремятся улучшить качества контрольно-измерительных методик.

\section{ФАКТОРЫ, ОБУСАОВАИВАЮЩИЕ ПРОЦЕССЫ СТАНААРТИЗАЦИИ В ТРУАОВЫХ ОТНОШЕНИЯХ И ОБРАЗОВАНИИ}

Россия заинтересована применить апробированный международный опыт стандартизации в сфере трудовых отношений, обучения и образования для оптимизации использования человеческого капитала на собственном рынке труда.

Общемировые глобальные процессы, связанные с выходом за национальные границы экономических и социальных процессов, создают идентичные экономи- 
ческие и социальные проблемы в различных странах. В контексте данной темы надо отметить следующее. Во-первых, демографические проблемы Европейского континента, связанные с вымиранием «коренного населения» из-за низкой рождаемости и старения населения, вызывают хронический дефицит трудовых ресурсов, что объясняет миграционную политику стран Евросоюза. Из материалов исследовательского центра CESifo (Center for Economic Studies (CES) and CESifo $\mathrm{GmbH})$ следует, что Германия в течение 10 лет будет ежегодно остро нуждаться в сотнях тысяч приезжей квалифицированной рабочей силы, прежде всего в медицине и промышленности (Мануков, 2015: Электронный ресурс). На Аавосском форуме 2016 г. глава МВФ К. Аагарф объяснила, что «при условии успешной и быстрой интеграции мигрантов в европейский трудовой рынок в 2010 г. дополнительный рост ВВП может составить 0,25\% для всего ЕС и в пределах 0,5-1,1\% Аля Австрии, Германии, Швеции» (Борцов, 2016: Электронный ресурс).

Во-вторых, общее повышение мобильности населения, и в частности миграция, ставят задачи не только трудоустройства, но прежде всего рационального использования имеющегося квалификационного потенциала кадров. Масштаб людских потоков можно представить по статистике ООН: в 2010 г. из 214 млн международных мигрантов в мире 50 млн проживали в Северной Америке и 70 млн - в Европе (В Нью-Йорке начала работу ..., 2013: Электронный ресурс), по последним сведениям, официально за 2015 г. более 1,2 млн человек обратились в ЕС с просьбой предоставления убежища.

По данным Федеральной миграционной службы РФ, с 2007 г. в Россию переселилось свыше 400 тыс. человек только по Программе переселения соотечественников, а постоянно на территории находится свыше 10 млн мигрантов. Есть прогнозы, что дефицит рабочей силы на рынке труда РФ возрастет до 18-20 млн к 2025 г. (Миграция в России ... : Электронный ресурс). Такое перемещение масс трудоспособного населения требует унификации системы оценки качества заявляемых профессиональных компетенций и, соответственно, сопоставимости и достоверности сертификатов о полученном образовании в разных странах.

В-третьих, Аругой глобальной проблемой, влияющей на качество человеческого капитала, является экспоненциальный рост информационной энтропии (Arbesman, Christakis, 2011: Электронный ресурс), приводящей к быстрому устареванию знания как научного, так и специализированного отраслевого. Например, приводятся такие данные: в бизнесе знания устаревают каждые 2 года; в металлургии - 3,9 года; в химической промышленности - 4,8 года; в рекламе 5 лет; в машиностроении - 5,2 года и т. А. (Шестаков, 2012: Электронный ресурс). Это обусловливает регулярное выделение времени и ресурсов на поиск обновленной информации или периодического обучения.

В-четвертых, косвенный аргумент актуальности использования общепризнанных и единообразных в международной практике подходов к кадрам связан с функционированием фондового рынка, поскольку в индикаторах, повышающих рейтинг компании, учитывается качество трудовых ресурсов. 150 крупнейших российских работодателей прошли IPО и делают отчеты по международным методикам.

В-пятых, интеграционные процессы в бизнес-среде (создающие зарубежные представительства компаний, международные инвестиционные проекты, совместные предприятия или совместные доли компаний) требуют унификации бизнес- 
практик, в частности в делопроизводстве и в отчетности, в том числе в кадровых вопросах. По данным Федеральной службы государственной статистики, в России функционирует около 24 тыс. предприятий и организаций с участием иностранного капитала (Основные показатели деятельности ... : Электронный ресурс). Особенно это типично для области исследований, рекламы, маркетинговых коммуникаций.

B-шестых, частным фактором, влияющим на институционные инновации в сфере труда, стало внедрение систем менеджмента качества и упрощение прохождения аудита по системе международных процессуальных стандартов ISO 9000-22000 (в Российской версии ИСО 9001-2000), где также учитывается кадровая политика предприятия. Ежегодный обзор ISO Survey-2014 показывает, что в мире 1609294 компании получают сертификаты данного типа (Сертификация ... : Электронный ресурс).

Строительство единых әкономических пространств (разного масштаба) определяет единые подходы к оценке трудовых ресурсов, сертификации кадров и принципов их совершенствования. Создается универсальный механизм сопряжения системы профессионального образования и обучения (далее - ПОО, англ. Vocational Education and Training, VET) разных стран с потребностями рынка труда. С этой целью требования со стороны работодателя должны быть формализованы и унифицированы через нормативы, квалификации, стандарты и т. п. Следующий шаг — интернирование данных требований в систему образования, верификация получаемых результатов образования, стимулирование участия работников в постоянном повышении квалификации, проводя линию так называемого обучения в течение всей жизни (Life Long Learning, LLF).

Реформирование трудовых отношений на новом глобальном уровне в Европе решалось в рамках стратегии занятости и экономического развития всего Евросоюза, через принятие ряда нормативных документов, создание специализированных структур и учреждений.

\section{ГЕНЕЗИС ПРАВОВОГО ОБЕСПЕЧЕНИЯ ЕАИНОГО ОБРАЗОВАТЕАЬНОГО И ЭКОНОМИЧЕСКОГО ПРОСТРАНСТВА ЕВРОПЫ}

В 1994 г. на Венском заседании Генеральной ассамблеи ООН была принята официальная прокламация Аекады ООН по правам человека в образовании на 1995-2004 гг. и разработан план действий на десятилетие. Общей идеей плана действий стало «уважение прав человека на образование и фиксация соответствующей структуры направлений действий в национальном законодательстве» (цит. по: Ягофаров, 2005: Электронный ресурс), при этом каждая страна искала собственные пути совершенствования системы образования, что даже закреплялось в нормативных документах. Но параллельно шла работа по выработке единой нормативной базы для соглашений в области образования. Конвенция о признании квалификаций, относящихся к высшему образованию в Европейском регионе (принятая в 1997 г. в Аиссабоне), стала первым таким документом создания правового механизм международного сотрудничества в области образования для более чем 50 стран мира (все государства Европы, СНГ, а также Австралия, Израиль, Канада, США). Под квалификациями в Конвенции подразумеваются самые разные документы, подтверждающие полученное образование и академическое признание (аттестаты, дипломы и академические справки о прохождении периодов обу- 
чения). Конвенция закрепляет два основных инструмента, позволяющих корреспондировать квалификации разных стран. Во-первых, это Европейская система перевода «кредитов» (European Credit Transfer System - ECTS), т. е. универсальных единиц измерения трудоемкости изучения дисциплины, и Приложение к диплому, в котором дается детальное описание квалификации, перечень учебных дисциплин, полученные оценки и кредиты.

Почти синхронно происходила институализация трудовых отношений на новом глобальном уровне в рамках стратегии занятости и экономического развития всего Евросоюза через принятие ряда нормативных документов и создание специализированных институтов и учреждений. Аиссабонская резолюция (принята на заседании Европейского Совета в марте 2000 г.) содержит тезис о построении «экономики, основанной на знаниях» как средства повышения конкурентоспособности Европы в мире. В реализации Аиссабонской декларации участвуют 31 страна и европейские социальные партнеры (Европейская конфедерация профсоюзов, Союз конфедераций промышленников и работодателей Европы, Европейская ассоциация малых и средних ремесленных предприятий, Европейский центр предприятий с частичным участием государства и предприятий общеэкономического интереса). Иначе говоря, новые документы уже объединяют субъектов на рынке труда и образования, ответственных за развитие человеческого капитала, социальной политики и политики в области занятости.

В последующие годы вся документальная база концентрировалась вокруг двух мегапрограмм, называемых процессами. Во-первых, это Болонский процесс, старт которому был дан в 1999 г. в Болонье, после одобрения министрами образования 29 стран Европы Аекларации о формировании единого Европейского пространства для высшего образования. К реализации данного процесса через четыре года присоединилась Россия (подписав в 2003 г. в Берлине Аекларацию вместе еще с 17 странами). Аанный документ ориентирован на регулирование вопросов высококвалифицированных кадров высшего управленческого звена.

Во-вторых, это так называемый Копенгагенский процесс (известный в России только в узких специализированных кругах). Начало ему было положено через очередную Аекларацию в 2002 г. Он связан с развитием обучения на разных уровнях в течение всей жизни человека и предполагает вовлечение в этот процесс помимо образовательных структур различных заинтересованных акторов (прежде всего союзы работодателей и работников, называемые в документах «социальными партнерами»).

В Европе Копенгагенский процесс, объемлющий все уровни образования, подчинил себе Болонский. Научно-методическую работу в рамках этого процесса ведут специализированные структуры, так называемые агентства ЕС (органы определенного направления): Европейский центр по развитию профессионального образования (фр. Centre Européen pour le Développement de la Formation Professionnelle, Cedefop) и Европейский фонд образования (англ. Evropinium Trening Fond, ETO).

Непосредственно в реализацию Копенгагенского процесса вовлечены национальные и общеевропейские институты, такие как Европейский центр высшего образования ЮНЕСКО, Европейская сеть служб занятости, Европейская сеть национальных информационных центров по вопросам признания академических 
квалификаций, учрежденная Советом Европы и ЮНЕСКО, а также структуры Международной организации труда (МОТ). С целью общественного признания предлагаемых разработок были созданы социальные сети с участием специалистов социальных партнеров и чиновников ЕС, заработала информационная система на 22 языках мира - Ploteus (www.ploteus.net).

В рамках этого процесса были разработана программа европейского сотрудничества в области образования и обучения (ЕT 2020) и принято Брюггское коммюнике, способствующее развитию мобильности как обучающихся, так и работников. В этом документе изложены рекомендации по стандартизачии информачии о навыках и квалификациях работников на европейском пространстве через национальные квалификационные рамки, корреспондирующиеся с результатами обучения, и профессиональные стандарты. Хотелось бы акцентировать внимание на то, что многие международные стандарты ориентированы именно на условное качество предоставляемой информации и эффективность информационных процессов, формализуя классификаторы, отчеты, проекты.

Копенгагенский процесс смог внедрить единые механизмы интеграции систем профессионального образовании и обучения (VET) и трудоустройства. В число приоритететов вошла разработка следующих систем:

1. EUROPASS - единая основа для прозрачности квалификаций и компетенций, введена с 2005 г., включает следующие документы: европейское резюме (Curriculum Vitae - CV); Europass-language portfolio (свидетельство экстралингвистической и межкультурной компетентности), оценивается Общеевропейской языковой шкалой (Common European Framework of Reference) и рядом сертификатов, подтверждающих владением аудированием, чтением, говорением и письмом); Europass-mobility (документы об активностях, связанные с обучением); два вида Europass-certificate supplement (приложения к дипломам о высшем образовании и о начальном профессиональном);

2. Европейская кредитная система перевода и накопления баллов (European Credit Transfer and Accumulation System - ECTS), Европейская система накопления и переноса зачетных единиц для профессионального образования (ECVET);

3. Европейская система обеспечения качества ПОО, включая Европейскую справочную рамку (European Quality Assurance Reference Framework for VOT$E Q A R F)$.

Подходы к профессиональному образованию и обучению, заложенные Копенгагенским процессом, распространяются почти на 50 стран мира (все государства Европы, СНГ, а также Австралия, Израиль, Канада, США).

Отметим, что Россия официально не вступила в Копенгагенский процесс, но последовательно выполняет многие решения, принимаемые в его рамках. Благодаря работе ETF, со всеми странами - участниками ЕС было согласовано, что любой современный стандарт ПОО должен включать как минимум следующие три компонента: 1) требования в трудовой сфере; 2) требования в области обучения; 3 ) требования в области оценки результатов обучения (Олейникова, Муравьева, 2006). Россия буквально перенесла общепринятые подходы к структуре ФГОС любого уровня, а теперь осваивает инструментарий Копенгагенского процесса в форме квалификаций и профессиональных стандартов. В 2016 г. готовится Федеральный закон РФ «О независимой оценке квалификаций» - еще один шаг 
к документальному подтверждению личной профессиональной траектории через профессиональное сообщество.

Если в Аиссабонской резолюции ${ }^{1}$ под квалификациями подразумевались любые сертификаты о высшем образовании, то сегодня квалификация определяется как «официальный результат процедур оценки и официального признания, который присуждается при условии принятия решения уполномоченным органом о достижении индивидуумом результатов обучения в соответствии с определенными стандартами» (Совершенствование системы ... : Электронный ресурс), что требует создания институтов, занимающихся данной оценкой. Возможность объективной оценки результатов обучения должна поощрять развитие личных траекторий обучения (формального и неформального характера) человека. Концепция образования в течение всей жизни закрепляется как правовая категория и транслируется во все национальные нормативы, связанные с образованием. Например, в Законе «Об образовании в Российской федерации» сказано: «Государственная политика и правовое регулирование отношений в сфере образования основываются на следующих принципах <..>8) обеспечение права на образование 8 течение всей жизни в соответствии с потребностями личности, адаптивность системь образования $\kappa$ уровню подготовки, особенностям развития, способностям и интересам челоВека» (курсив наш. - А. Б., А. Г.) (Федеральный закон от 29 декабря ..., 2012: Электронный ресурс). Но инфраструктура для этого только создается, о чем ниже.

\section{МЕЖАУНАРОДНЫЙ ОПЫТ СТАНААРТИЗАЦИИ ИНФОРМАЦИИ}

В СФЕРЕ ТРУАА

Универсальным документом стала Европейская рамка квалификаций (Еuropean Qualification Frame - EQF), предложенная в Европе в 2008 г. В рекомендациях Европейского парламента сказано, что к 2020 г. персональные квалификационные свидетельства должны содержать данные о соответствии конкретному уровню EQF (Recommendation of the European Parliament ... : Электронный ресурс). Эта рамка содержит описание (дискрипты) восьми уровней, в терминах знаний (Knowledge), умений (Skills) и компетенций (Competence), которые определяют качественное отличие квалификаций одного уровня от другого.

Есть еще группа стандартов, затрагивающих область трудовых отношений, но имеющих самостоятельный статус и разрабатываемых вне агентств ЕС. В трансконтинентальной практике различные виды регламентов производственной деятельности унифицированы через стандарты Международной организации по стандартизации (International Organization for Standardization - ISO). В новом тысячелетии начинают прописываться стандарты интеллектуальной деятельности и бизнес-процедур (типа Менеджмента качества, серии ISO 9000:2005 или Руководства по социальной ответственности, ISO 2600). Появляются белее узкие стандарты управленческих видов деятельности, например, ISO 10006:2003, Quality management systems - Guidelines for quality management in projects (в России принят как ГОСТ Р ИСО 10006-2005. Системы менеджмента качества. Руководство по менеджменту качества при проектировании) и ISO 21500:2012 Guidance on project management (в России принят как ГОСТ Р ИСО 21500-2014. Руководство по проектному менеджменту). В этих документах также уделяется внимание качеству трудовых ресурсов, что стимулирует развитие систем совершенствования челове- 
ческого капитала на региональном уровне. Но национальные структуры, аффилированные с ISO, могут не иметь прямых связей с институтами образования и трудовых отношений. Так, в России всеми аспектами адаптации международных стандартов и легитимизации новых занимается Федеральное агентство по техническому регулированию и метрологии (Ростехрегулирование), которое никак не заявлено в системе создания профессиональных стандартов. Внедрению квалификационной рамки содействовали разъяснительные публикации Европейского центра по развитию профессионального образования (Cedefop), по обеспечению взаимосвязи между качеством образования и сертификацией в системе ПОО в государствах - членах ЕC, благодаря чему в большинстве стран приняты национальные квалификационные рамки, корреспондирующиеся с EQF. В 2007 г. Министерство образования и науки РФ смогло утвердить Национальную рамку квалификаций РФ, разработанную на основании Соглашения о взаимодействии с Российским союзом промышленников и предпринимателей (Национальная рамка ... , 2008). На повестке дня стоит задача по созданию отраслевых рамок для каждой области профессиональной деятельности.

Материалы еще одной глобальной структуры также не всегда учитываются в европейских реформах ПОО. В системе Международной организации труда разработан Международный стандарт классификации видов деятельности (International Standard Classification Occupations - ISCO) с девятью квалификационными уровнями (а не восьмью $E Q F)$. Это более близкий подход, соответствующий Общероссийскому классификатору занятий РФ (ОКЗ), описывающий виды занятости населения в соответствии с девятью уровнями национальной квалификационной рамки. Например, группа высшей квалификации МОТ разделана на четыре подгруппы на основании областей деятельности: 11 - руководители, старшие должностные лица и законодатели; 12 - административные и коммерческие руководители; 13 - менеджеры в области производства и специализированных услуг; 14 - менеджеры в сфере гостеприимства, розничной торговли и других услуг. При этом в российском аналоге - Общероссийском классификаторе занятий (ОКЗ) РФ разделение занятий идет по основанию полномочий и степени ответственности. Поэтому там к «высшим должностям» относятся в укрупненной группе «руководители органов власти и управления всех уровней, включая руководителей учреждений, организаций и предприятий» в трех подгруппах, образованных по принципу меры ответственности и масштаба деятельности: 11 - руководители (представители) органов власти и управления, 12 руководители учреждений, организаций и предприятий и их структурных подразделений (служб), 13 - руководители малых учреждений, организаций и предприятий.

Наиболее эффективно решает проблемы кадрового дефицита на своей территории Великобритания. Это страна, ограниченная в природных ресурсах, традиционно делала ставку на развитие человеческого потенциала. Поэтому Национальная система обеспечения высококачественными специалистами для разных отраслей через подготовку и постоянное совершенствование кадров стала инструментом экономической стратегии. Ее составляют:

- национальные профессиональные стандарты (National Occupational Stan$d a r d s-N O S)$, в том числе в области менеджмента - Национальный профессио- 
нальный стандарт по менеджменту и администрированию (National Occupational Standards for management and leadership), с кратким описанием основных трудовых функций;

- советы по развитию отраслевого мастерства (квалификаций) (Sector Skills Councils), проводящие оценку и сертификацию кадров или специальные рабочие группы по разработке стандартов (Standards setting bodies). На сегодня в Великобритании действует 23 таких Совета;

- Национальная рамка квалификаций, состоящая из восьми уровней и описывающая все возможные виды образования, а также пути получения профессиональной подготовки;

- Национальное квалификационное агентство при Правительстве Великобритании (United Kingdom national agency for the recognition and comparison of international qualifications and skills - UK NARIC) - квалификационный регулятор, который координирует соответствие требований работодателей с квалификациями иностранных претендентов на вакансии, а технически ведет мониторинг и аккредитацию органов присвоения квалификаций;

- система переаттестации и подтверждения результатов предыдущего образования;

- программы профессионального образования и обучения (для возрастных групп от 14 лет и старше), обеспечивающие взаимосвязь различных уровней и типов обучения; сеть автономных колледжей и частных учебных заведений, реализующих программы профессионального обучения в тесном сотрудничестве с региональными организациями работодателей.

Например, профессиональные стандарты Великобритании в области рекламы принимаются с 2010 г. и постоянно обновляются (приблизительно раз в три года). В настоящее время разработаны около 343 стандартов, где упоминается слово «реклама», например: «Разработка медиаплана для рекламы товаров (услуг)», «Планирование и проведение рекламы собственной деятельности в творческой и культурной индустрии» (по содержанию это «самопродвижение» в сфере культуры, искусства, шоу-бизнеса). Но все это относится к разным группам областей деятельности: 1. «Маркетинг и управление продажами; смежные области с маркетингом» (86 стандартов), «Искусство, медиа (СМИ) и издательская деятельность; Средства массовой информации и коммуникации; специалисты по смежным со СМИ видам деятельности» (47); «Аиректор по рекламе и связям с общественностью; Специалист по связям с общественностью» (9); «Розничная торговля и коммерческое предприятие; Сервисные предприятия; Персональный сервис; Профессии Парикмахеры и смежные профессии» (3 стандарта, связанные с организацией промоакций). Остальное распределено по разным другим видам, например «Производственные технологии» (3 стандарта), которые можно использовать с целью рекламы, упаковки и т. д.

Опыт Великобритании интересен своим системным подходом, хотя структура областей и видов деятельности имеет оригинальную специфику, видимо, сложившуюся за исторический период противопоставления себя континенту, и не адекватна общепринятым классификациям, например в МОТ. Названия самих стандартов и их содержание не имеют строгой архитектуры, скорее похожи на требования к вакансии при приеме на работу. 
Развивается система профессиональной квалификации в СНГ. С учетом активизации миграции не только с сопредельных с Европой территорий, но и из бывших республик Советского Союза в область реформ вовлечены страны, расположенные как в Восточной Европе, так и в Центральной Азии, в зоне Южного и Восточного Средиземноморья. Например, в материалах Европейского фонда образования (ETF) «Совершенствование системы профессиональных квалификаций» представлено исследование хода реформирования системы профессиональных квалификаций в странах - партнерах фонда (Совершенствование системы .... Электронный ресурс) из вышеперечисленных географических регионов (в том числе Казахстана, Узбекистана, Молдавии и т. п.).

Надо учитывать, что траектория реформ в странах СНГ (поставляющих в Россию рабочую силу) идет крайне неравномерно. Показательна ситуация с Белоруссией. Высшее образование Белоруссии на уровне преподавательских кадров вполне интернировано в Европейскую систему образования, в том числе получением грандов на исследования, участием в конференциях за рубежом, стажировками. Но Белоруссия, подписав Ииссабонскую декларацию 1997 г., так и не вступила в Болонский процесс, поэтому системных изменений в образовании и на рынке занятости не произошло. Возникает вопрос: каким образом верифицировать документы о квалификации при найме приезжающих из этой республики? Решению этой проблемы посвящено постановление Совета Министров РБ за № 34 от 17 января 2014 г. «О некоторых вопросах развития национальной системы квалификаций Республики Беларусь».

В образовательной практике Украина (подписала Болонскую хартию в 2005 г.) пошла своим путем и создала четырехступенчатую систему: в структуру высшего образования Украины входят образовательные уровни (неполное высшее образование, базовое высшее образование, полное высшее образование) и образовательно-квалификационные уровни (младший специалист, бакалавр, специалист, магистр) (Образовательные квалификационные уровни: Электронный ресурс). Естественно возникают проблемы сопоставления таких квалификаций с российскими при трудоустройстве мигрантов.

\section{РОАЬ ПРОФЕССИОНАИЬНЫХ СТАНААРТОВ \\ В РЕГУАИРОВАНИИ РЫНКА ТРУАА В РОССИИ}

Рассмотрим новые институты системы регулирования труда, занятости и образования в Российской Федерации. Традиционным инструментом контроля за рынком труда, предупреждения трудовых конфликтов является дифференцирование трудовых ресурсов по разным родам занятий, а предприятий и учреждений - по видам деятельности. С этой целью функционируют Общероссийский классификатор видов экономической деятельности (ОКВЭА), коды которого указываются при регистрации индивидуального предпринимателя и общества с ограниченной ответственностью, и Общероссийский классификатор занятий (ОКЗ), где описаны разные виды профессиональной деятельности и соответствующие квалификации.

Аругим нормативным документом является Квалификационный справочник должностей руководителей, специалистов и других служащих, в котором представлены общеотраслевые квалификационные характеристики должностей работ- 
ников, занятых на предприятиях, в учреждениях и организациях (Квалификационный справочник ... : Электронный ресурс). Этот реестр постоянно обновляется в соответствии с появлением новых видов профессий, например, только в 2008 г. было дано описание должности «Аиректор по связям с инвесторами». Трудовые инспекции традиционно опираются на данные материалы при проверке документооборота кадровых служб.

Понятие профессиональных стандартов актуализировалось благодаря нескольким инициативам предпринимательских кругов, поддержанных правительством, но до 2012 г. было утверждено всего около 70 стандартов. Импульсом к разработке профессиональных стандартов стала уже упоминавшаяся статья Президента РФ в «Комсомольской правде» (Путин, 2012). За последующие три года структурами Министерства труда и социальной защиты РФ был разработан инструментарий для создания и внедрения профессиональных стандартов, включающий Правила разработки, утверждения и применения профессиональных стандартов (утверждены постановлением Правительства РФ от 22 января 2013 г. № 23). Создан информационный портал «Профессиональный стандарт» (http://profstandart.rosmintrud.ru/), где представлена вся нормативная база, а также можно заявить о начале работы над стандартом и «забронировать» определенное направление на полтора года (условие первичности подаваемой заявки). С 2014 г. заработал Национальный совет при Президенте Российской Федерации по профессиональным квалификациям, аккумулирующий интеллектуальные ресурсы бизнеса, образования и профсоюзов, главными целями которого является координация деятельности по «приведению федеральных государственных стандартов профессионального образования в соответствие с профессиональными стандартами; по профессионально-общественной аккредитации образовательных программ профессионального образования; по формированию системы независимой оценки профессиональной квалификации» (О Национальном совете ... : Электронный ресурс). Структура Совета и персональный состав участников (чиновники, руководители крупных промышленных союзов, отраслевых общественных организаций, госкорпораций, а также ректоры крупнейших университетов) свидетельствует о комплексном подходе к решению поставленных задач и больших полномочиях данного органа. Необходимо отметить, что в Совет входят три главы министерств (труда и социальной защиты, промышленности и торговли, образования и науки), а секретариат возглавляет заместитель министра труда и социальной защиты РФ. Межведомственная площадка консолидирует профессиональное сообщество и должна снимать противоречия между интересами субъектов. Именно этот орган выносит решение об утверждении профессиональных стандартов. В конце $2015-$ начале 2016 г. Министерство труда предприняло несколько действий для стимулирования работы над стандартами.

Несмотря на созданную инфраструктуру, выделяемые целевым назначением средства, а также информационную и технологическую поддержку, план по внедрению 800 профессиональных стандартов на 2014 г. был с трудом выполнен в 2015 г.

Открытая система для инициатив (crowdsourcing) не подразумевает логической структурированности профессионального трудового пространства. Названия 809 стандартов реестра также не вносят определенности. 
На наш взгляд, необходимо централизованно упорядочивать названия, определять кодовые слова, создавать некую иерархию в понятиях. «Специалист» как квалификация ушла из системы образования. Администраторы проекта этой глобальной реформы, возможно, думали, что что-то родится из отраслевых квалификационных рамок, которые разрабатываются параллельно с профессиональными стандартами в каждой отрасли, но эта работа затормозилась, поскольку утвержденных хоть какой-то инстанцией методических рекомендаций для их создания не существует.

При сопряжении с образовательными стандартами хаос с названиями естественно будет затруднять работу, хотя ФГОС и может базироваться на нескольких ПС. Аругой аспект будет заключается в том, что отсутствует единый подход к описанию результатов обучения в профессиональном дискурсе и образовательном. И в европейских документах результаты обучения, характеризующиеся тем, что обучающийся должен знать, понимать и уметь делать (ЗПУ) после завершения курса обучения, не всегда соотносятся с трудовой практикой. Требования в профессиональных квалификациях часто базируются на компетенциях как способности выполнять конкретную трудовую функцию. В европейских нормативах принято, что оба подхода можно использовать взаимозаменяемо, а компетенция может быть представлена как в широком понимании - как уровни способностей и умения, так и в узком - применение знаний на практике. Такая неоднозначность понятия вызывает проблемы в адаптации данных подходов к российской педагогической практике, где в ФГОС появились «общекультурные компетенции» - не имеющие аналогов в мире.

Показатели уровней квалификации в трудовых отношениях не оформляются в виде компетенций. В Макете профессионального стандарта трудовая функция раскрывается через трудовые действия, знания, навыки.

\section{ЗАКАЮЧЕНИЕ}

Проведенное исследование позволяет сделать вывод, что, несмотря на некоторые частные искажения, создается достаточно монодитное нормативное пространство на всей территории Европейского союза и стран СНГ в контексте реформ в области образования и труда. Профессиональный стандарт - один из элементов механизма данных реформ, проводимых с целью развития трудовых ресурсов через сопряжение системы образования и требований рынка труда в конкретной сфере. Аанный инструмент будет эффективно работать только при условии создания полноценной системы профессионального образования и обучения, интегрированной с трудовой деятельностью.

В идеале в реформе трудовых отношений, занятости и образования заинтересованы различные субъекты общественных отношений, которые могут получить собственные дивиденды. Работодатели смогут более адекватно оценить претендентов на вакансии и эффективнее использовать их труд. Аля посредников по поиску персонала, рекрутинговых агентств и кадровых служб предприятий облегчается поиск и оформление работников, кадровый документооборот. Аля образовательных учреждений ориентация на профессиональные стандарты позволяет дать лучшие начальные условия для выпускников. Аля государственных структур, регулирующих коммерческую деятельность, трудовые отношения и занятость насе- 
ления, упростятся процессы координации и контроля. Выиграют отраслевые общественные организации, осваивающие новые виды деятельности, через право проводить независимую оценку квалификаций, сертифицировать как работников, так и образовательные программы. В перспективе данные преобразования должны усилить конкурентоспособность конкретной отрасли в мировой системе хозяйствования.

\section{ПРИМЕЧАНИЕ}

1 Аиссабонская резолюция принята на заседании Европейского Совета в марте 2000 г. Содержит официальное признание центральной роли образования как фактора экономической и социальной политики, а также как средства повышения конкурентоспособности Европы в мировом масштабе, сближения ее народов и полноценного развития граждан.

\section{СПИСОК АИТЕРАТУРЫ}

Федеральный закон от 2 мая 2015 г. № 122-Ф3 «О внесении изменений в Трудовой кодекс Российской Федерации и статьи 11 и 73 Федерального закона “Об образовании в Российской Федерации” (2015) [Электронный ресурс]// Российская газета. Федеральный выпуск № 6666 (95). 6 мая. URL: https://rg.ru/2015/05/06/trk-dok.html (дата обращения: 21.01.2016).

Федеральный закон от 29 декабря 2012 г. № 273-Ф3 «Об образовании в Российской Федерации» [Электронный ресурс] // Российская газета. 31 декабря. №5977 (303). URL: http://rg.ru/2012/12/30/obrazovanie-dok.html (дата обращения: 20.02.2016).

Борцов, А. (2016) МВФ: Миграционный кризис полезен Европе [Электронный ресурс]// Политическая Россия : общественно-политический интернет-журнал. 25 января. URL: http://politrussia.com/world/mvf-za-migrantov-363/ (дата обращения: 30.02.16).

В Нью-Йорке начала работу Комиссия ООН по народонаселению и развитию (2013) [Электронный ресурс] // Центр новостей ООН. 22 апреля. URL: http://www.un.org/russian/news/story.asp?NewsID=19432\#.VtmFhn2LSHs (дата обращения: 30.02.2016).

Квалификационный справочник должностей руководителей, специалистов и других служащих. 4-е изд., доп. (утв. постановлением Минтруда РФ от 21 августа 1998 г. № 37) (с изменениями и дополнениями) [Электронный ресурс]// Система ГАРАНТ. http://base. garant.ru/180422/\#ixzz4DensoYDg (дата обращения: 30.02.2016).

Мануков, С. (2015) Германия нуждается в мигрантах [Электронный ресурс]// Expert Online. 28 апреля. URL: http://www.expert.ru/2015/04/28/germaniya-nuzhdaetsya-v-migrantah/ (дата обращения: 30.02.2016).

Миграция в России 2016 [Электронный ресурс] // Новости России и CHГ. URL: http://rusdni.ru/obschestvo/migraciya/migraciya-v-rossii-2015.html (дата обращения: 01.02.2016).

Минтруда России дает разъяснения по вопросам о применении профессиональных стандартов в сфере труда (10 февраля 2016 г.) (2016) [Электронный ресурс]// Координационный совет учебно-методических объединений и научно-методических советов высшей школы (Портал Федеральных образовательных стандартов высшего образования). 3 марта. URL: http://fgosvo.ru/news/21/1799/ (дата обращения 23.02.2016).

Национальная рамка квалификаций Российской Федерации: Рекомендации (2008) / О. Ф. Батрова, В. И. Блинов, И. А. Волошина [и др.]. М. : Федеральный институт развития образования. 14 с.

О Национальном совете [Электронный ресурс]// Национальный совет при Президенте Российской Федерации по профессиональным квалификациям. URL: http://nspkrf.ru/ about.html (дата обращения: 20.02.2016). 
Образовательные квалификационные уровни [Электронный ресурс]// Национальный информационный центр Академической мобильности ENIK UKRAINE. URL: http:// enic.in.ua/index.php/ru/sistema-obrazovania/vysshee/obrazovatelno-kalifikacionnie-urovni (дата обращения: 30.02.2016).

Олейникова, О. Н., Муравьева А. А. (2006) Копенгагенский процесс. М. : Центр изучения проблем профессионального образования. 132 с.

Основные показатели деятельности организаций с участием иностранного капитала по видам деятельности [Электронный ресурс]// Федеральная служба государственной статистики. URL: http://www.gks.ru/free_doc/new_site/business/inst-preob/tab-opi1.htm (Аата обращения: 30.02.2016).

Путин, В. В. (2012) Строительство справедливости. Социальная политика для России // Комсомольская правда. 13 февраля. С. 1.

Приветствие президента Российского союза промышленников и предпринимателей, председателя Национального совета при Президенте Российской Федерации по профессиональным квалификациям Александра Николаевича Шохина // Сборник материалов к Всероссийскому форуму «Национальная система квалификаций России. Практические шаги системных изменений». С. 5-6 [Электронный ресурс]// Dropbox.com. URL: https:// www.dropbox.com/s/ixdso52u080gwuo/sbornik_nspk_dec2015_disc.pdf?dl=0 (дата обращения: 30.02.2016).

Сертификация... стандарты ИСО на системы менеджмента [Электронный ресурс]// ISO. International Standard Organization. URL: http://www.iso.org/iso/ru/home/standards/certification.htm (дата обращения: 30.02.2016).

Совершенствование системы профессиональных квалификаций. Реформирование системы профессиональных квалификаций в странах - партнерах ЕФО [Электронный ресурс]// ETF. URL: http://www.etf.europa.eu/webatt.nsf/0/46F0394EFF6863B6C1257CAD004D7CCB/ \$file/Making\%20better\%20vocational\%20qualifications_RU.pdf (дата обращения: 30.02.2016).

Состоялся Всероссийский форум «Национальная система квалификаций России. Практические шаги системных изменений» [Электронный ресурс]// Национальный совет при Президенте РФ по профессиональным квалификациям. URL: http://nspkrf.ru/ news-nspk/item/46-forum-2015.html (дата обращения: 30.02.2016).

Шестаков, М. (2012) Организация разработки профессиональных стандартов в Великобритании [Электронный ресурс] // ЦБНТ. Центральное бюро нормативов по труду. URL: http://cbnt.ru/analytics/professional_standarts/2012/6 (дата обращения: 01.05.2016).

Ягофаров, А. А. (2005) 10.1.2. Европейское образовательно-правовое пространство и «болонский процесс» / Правовое регулирование системы образования : учебное пособие [Электронный ресурс]// Федеральное государственное бюджетное учреждение Федеральный центр образовательного законодательства. URL: http://www.lexed.ru/obrazovatelnoepravo/knigi/yagofarov2005/1012.php (дата обращения 30.02.2016).

Arbesman, S., Christakis, N. A. (2011) Eurekometrics: Analyzing the Nature of Discovery [Электронный ресурc] // PLoS Comput Biol 7(6): e1002072. URL: http://journals.plos. org/ploscompbiol/article?id=10.1371/journal.pcbi.1002072 (дата обращения: 30.02.2016). DOI:10.1371/journal.pcbi.1002072

Recommendation of the European Parliament and of the Council on the establishment of the European Qualifications Framework for lifelong learning, 2008 [Электронный pecyрc]// The European Qualifications Framework for lifelong learning (EQF). European Communities, 2008. URL : http://www.ond.vlaanderen.be/hogeronderwijs/bologna/news/EQF_EN.pdf (Aaта обращения: 10.05.2016). 
NORMATIVE AND METHODOLOGICAL BASES OF STANDARDIZATION

IN EMPLOYMENT AND EDUCATION:

RUSSIAN AND INTERNATIONAL EXPERIENCE

A. D. BORODAY

(MOSCOW UNIVERSITY FOR THE HUMANITIES),

A. G. GolOVA

(RUSSIAN STATE UNIVERSITY FOR THE HUMANITIES)

The President of the Russian Federation has assigned to the government the tasks of developing human resources and improving labor relations, primarily by means of convergence of the educational and labor systems and setting up a unified national system of qualifications and mechanisms to improve the level of qualification. For this purpose, a legal basis is being created to regulate new forms of relations in the labor market. To complement it, a special institutional body - the National Council on Professional Qualifications - has been set up under the aegis of the President of the Russian Federation to bring together employers, educators and government officials. The article describes the continuity within Russian and international experience of reforms in the sphere of labor and education, in the specific context of Russia's integration into a common European economic space, regardless of the global political situation.

Both globalization and the increasing mobility of the world's population have called for setting up a universal international system to help regulate labor markets and develop human resources by means of standardizing information and document management, as well as by establishing uniform principles of vocational education, training and certification. All of these factors found their way into the Bologna process of higher education, which was subsequently transformed into the Copenhagen process, covering the whole sphere of vocational education and training. As a result, a number of universal instruments arose, such as the EUROPASS, the European Credit System (ECTS), the European Qualifications Framework (EQF), the European system for ensuring the quality of vocational education and training, including an independent examination and certification of educational programs and people.

The norms and rules developed in international practice to ensure these processes are now being adapted for use in Russia, with professional and educational standards founded on the unified methodological basis forming a separate mechanism.

The article traces the trajectories the development of standardization took in the labor markets and educational systems on the European continent, in the UK and in the post-Soviet states. Particular attention is paid to Russia's practice of systematizing various types of professional activity and employment, as well as personnel qualification requirements as a basis for standardization. We conclude by asserting the importance of reforms in education and labor relations in order to provide the efficiency and stability of the Russian economy.

Keywords: professional standards; educational standards; national qualifications framework; Bologna process; Copenhagen process.

\section{REFERENCES}

Federal'nyi zakon ot 2 maia 2015 g. № 122-FZ «O vnesenii izmenenii v Trudovoi kodeks Rossiiskoi Federatsii i stat'i 11 i 73 Federal'nogo zakona "Ob obrazovanii v Rossiiskoi Federatsii” (2015). Rossiiskaia gazeta. Federal'nyi vypusk, no. 6666 (95), 6 May [online] Available at: https://rg.ru/2015/05/06/trk-dok.html (access date: 21.01.2016). (In Russ.).

Federal'nyi zakon ot 29 dekabria 2012 g. № 273-FZ «Ob obrazovanii v Rossiiskoi Federatsii» (2012). Rossiiskaia gazeta, 31 December, no. 5977 (303) [online] Available at: http:// rg.ru/2012/12/30/obrazovanie-dok.html (access date: 20.02.2016). (In Russ.). 
Bortsov, A. (2016) MVF: Migratsionnyi krizis polezen Evrope. Politicheskaia Rossiia, 25 January [online] Available at: http://politrussia.com/world/mvf-za-migrantov-363/ (access date: 30.02.2016). (In Russ.).

V N'iu-Yorke nachala rabotu Komissiia OON po narodonaseleniiu i razvitiiu (2013). Tsentr novostei OON, 22 April [online] Available at: http://www.un.org/russian/news/story. asp?NewsID=19432\#.VtmFhn2LSHs (access date: 30.02.2016). (In Russ.).

Kvalifikatsionnyi spravochnik dolzhnostei rukovoditelei, spetsialistov i drugikh sluzhashchikh. 4-e izd., dop. (utv. postanovleniem Mintruda RF ot 21 avgusta 1998 g. № 37) (s izmeneniami i dopolneniami). Sistema GARANT [online] Available at. http://base.garant.ru/ 180422/\#ixzz4DensoYDg (access date: 30.02.2016). (In Russ.).

Manukov, S. (2015) Germania nuzhdaetsia v migrantakh. Expert Online, 28 April [online] Available at: http://www.expert.ru/2015/04/28/germaniya-nuzhdaetsya-v-migrantah/ (access date: 30.02 .2016$)$. (In Russ.).

Migratsia v Rossii 2016. Novosti Rossii i SNG [online] Available at: http://rusdni.ru/ obschestvo/migraciya/migraciya-v-rossii-2015.html (access date: 01.02.2016). (In Russ.).

Mintruda Rossii daet raz'iasneniia po voprosam o primenenii professional'nykh standartov v sfere truda (10 fevralia 2016 g.) (2016). Koordinatsionnyi sovet uchebno-metodicheskikh ob'edinenii i nauchno-metodicheskikh sovetov vysshei shkoly. Portal Federal'nykb obrazovatel' nykh standartov vysshego obrazovania, March 3 [online] Available at: http://fgosvo.ru/ news/21/1799/ (access date: 23.02.2016). (In Russ.).

Natsional'naia ramka kvalifikatsii Rossiiskoi Federatsii: Rekomendatsii (2008), ed. by O. F. Batrova, V. I. Blinov, I. A. Voloshina et al. Moscow, Federal'nyi institut razvitiia obrazovaniia. 14 p. (In Russ.).

O Natsional'nom sovete. Natsional' nyi sovet pri Prezidente Rossiiskoi Federatsii po professional' nym kvalifikatsiam [online] Available at: http://nspkrf.ru/about.html (access date: 20.02.2016). (In Russ.).

Obrazovatel'nye kvalifikatsionnye urovni. Natsional'nyi informatsionnyi tsentr Akademicheskoi mobil'nosti ENIK UKRAINE [online] Available at: http://enic.in.ua/index. $\mathrm{php} / \mathrm{ru} /$ sistema-obrazovania/vysshee/obrazovatelno-kalifikacionnie-urovni (access date: 30.02.2016). (In Russ.).

Oleinikova, O. N. and Murav'eva A. A. (2006) Kopengagenskii protsess. Moscow, Tsentr izuchenia problem professional'nogo obrazovania. 132 p. (In Russ.).

Osnovnye pokazateli deiatel'nosti organizatsii s uchastiem inostrannogo kapitala po vidam deiatel'nosti. Federal'naia sluzbba gosudarstvennoi statistiki [online] Available at: http:// www.gks.ru/free_doc/new_site/business/inst-preob/tab-opi1.htm (access date: 30.02.2016). (In Russ.).

Putin, V. V. (2012) Stroitel'stvo spravedlivosti. Sotsial'naia politika dlia Rossii. Komsomol'skaia pravda, 13 February, p. 1. (In Russ.).

Privetstvie prezidenta Rossiiskogo soiuza promyshlennikov i predprinimatelei, predsedatelia Natsional'nogo soveta pri Prezidente Rossiiskoi Federatsii po professional'nym kvalifikatsiiam Aleksandra Nikolaevicha Shokhina. In: Sbornik materialov k Vserossiiskomu forumu «Natsional'naia sistema kvalifikatsii Rossii. Prakticheskie shagi sistemnykh izmenenii», pp. 5-6. Dropbox.com [online] Available at: https://www.dropbox.com/s/ixdso52u080gwuo/sbornik_nspk_dec2015_disc.pdf?dl=0 (access date: 30.02.2016). (In Russ.).

Sertifikatsia... standarty ISO na sistemy menedzhmenta. ISO. International Standard Organization [online] Available at: http://www.iso.org/iso/ru/home/standards/certification.htm (access date: 30.02.2016). (In Russ.).

Sovershenstvovanie sistemy professional'nykh kvalifikatsii. Reformirovanie sistemy professional'nykh kvalifikatsii v stranakh - partnerakh EFO. ETF [online] Available at: 
http://www.etf.europa.eu/webatt.nsf/0/46F0394EFF6863B6C1257CAD004D7CCB/\$file/Mak ing\%20better\%20vocational\%20qualifications_RU.pdf (access date: 30.02.2016).

Sostoialsia Vserossiiskii forum «Natsional'naia sistema kvalifikatsii Rossii. Prakticheskie shagi sistemnykh izmenenii». Natsional' nyi sovet pri rezidente RF po professional' nym kvalifikatsiiam [online] Available at: http://nspkrf.ru/news-nspk/item/46-forum-2015.html (access date: 30.02 .2016$)$. (In Russ.).

Shestakov, M. (2012) Organizatsiia razrabotki professional'nykh standartov v Velikobritanii. CBNT. Tsentral' noe biuro normativov po trudu [online] Available at: http://cbnt.ru/ analytics/professional_standarts/2012/6 (access date: 01.05.2016). (In Russ.).

Yagofarov, D. A. (2005) 10.1.2. Evropeiskoe obrazovatel'no-pravovoe prostranstvo i «bolonskii process» In: Pravovoe regulirovanie sistemy obrazovania : uchebnoe posobie. Federal'noe gosudarstvennoe biudzhetnoe uchrezhdenie Federal' nyi tsentr obrazovatel' nogo zakonodatel'stva [online] Available at: http://www.lexed.ru/obrazovatelnoepravo/knigi/yagofarov2005/1012.php (access date: 30.02.2016). (In Russ.).

Arbesman, S. and Christakis, N. A. (2011) Eurekometrics: Analyzing the Nature of Discovery. PLoS Comput Biol 7(6): e1002072 [online] Available at: http://journals.plos.org/ ploscompbiol/article?id=10.1371/journal.pcbi.1002072 (access date: 30.02 .2016 ). DOI:10.1371/ journal.pcbi.1002072

Recommendation of the European Parliament and of the Council on the establishment of the European Qualifications Framework for lifelong learning, 2008. The European Qualifications Framework for lifelong learning (EQF). European Communities, 2008 [online] Available at: http://www.ond.vlaanderen.be/hogeronderwijs/bologna/news/EQF_EN.pdf (access date: 10.05.2016).

Submission date: 15.05.2016.

Бородай Александр Амитриевич - доктор исторических наук, профессор, профессор кафедры теории рекламы и массовых коммуникаций, декан факультета рекламы Московского гуманитарного университета. Адрес: 111395, Россия, г. Москва, ул. Юности, д. 5. Тел.: +7 (499) 374-54-51. Эл. адрес: ad.bor@mail.ru

Голова Анна Георгиевна - кандидат социологических наук, доцент, доцент кафедры маркетинга и рекламы Российского государственного гуманитарного университета. Адрес: 125993, Россия, ГСП-3, г. Москва, Миусская площадь, д. 6. Тел.: +7 (495) 250-63-90. Эл. алpec: Golova.a@rggu.ru

Boroday Aleksandr Dmitrievich, Doctor of History, Professor, Department of theory of advertising and mass communications; Dean, Faculty of Advertising, Moscow University for the Humanities. Postal address: 5 Yunosti St., 111395 Moscow, Russian Federation. Tel.: +7 (499) 374-54-51. E-mail: ad.bor@mail.ru

Golova Anna Georgievna, Candidate of Sociology, Associate Professor, Department of marketing and advertising, Russian State University for the Humanities. Postal address: 6 Miusskaya Sq., 125993 GSP-3 Moscow, Russian Federation. Tel.: +7 (495) 250-63-90. E-mail: Golova.a@rggu.ru 